\title{
Mylos Root in Terminologia Anatomica
}

\author{
Raíz Mylos en Terminologia Anatomica
}

Schilin Wen'; Mariano del Sol ${ }^{2}$ \& Christopher Nicholson ${ }^{3}$

\begin{abstract}
WEN, S.; DEL SOL, M. \& NICHOLSON, C. Mylos root in Terminologia Anatomica. Int. J. Morphol., 38(1):126-128, 2020.
SUMMARY: The current International Terminologia Anatomica is written in latin and from it, the translation into the corresponding language is carried out. There are terms of greek origin that sometimes do not fully describe the anatomical structure. In this context, the mylos root, present in mylohyoid word, is defined in greek " like a mill" or "resembling a tooth". However, this definition does not accurately represent the mylohyoid structures that it describes. Therefore the question arises: is the mylos root the most appropriate one for naming these structures?
\end{abstract}

KEY WORDS: Terminologia Anatomica; Anatomical Terminology; Mylos root.

\section{INTRODUCTION}

Currently Terminologia Anatomica (TA) is the basis of medical terminology and it is important that doctors and researchers around the world use the same term to refer to the same structure (Federative Committee on Anatomical Terminology-FCAT, 2001). However for decades, anatomists called many structures either by objects names that have similar shape to the structure or naming them after themselves or even their teachers (Fuentes \& Ottone, 2017).

In 1989 the International Federation of Associations of Anatomists (IFAA) developed TA written in latin with translation into the corresponding language (Vásquez \& del Sol, 2015). In this regard, it has been established that the anatomical terms must have an informative value in accordance to the structure they denote, that is, they provide information of either its shape or function. However, it is still common to find terms of greek origin and names of structures that are not completely related to the above. Therefore, it is important to know the etymology of anatomical terms, thus facilitating the understanding of human anatomy and its study (Moya et al., 2017). This idea is supported by Smith et al. (2017), who concluded that the basic knowledge of latin and greek etymologies makes the learning and use of medical terminology easier for students and medical professionals.
In this context, we wanted to analyse the term mylohyoid which has greek origin and is composed by two words: mylos and hyoid (Cortés et al., 2011) where hyoid comes from the greek "hyodeides" which means "having the shape of letter Upsilon" (Dorland, 2007) and mylos will be analyzed in TA.

In the $T A$ there are five terms associated with mylohyoid: mylohyoid line, mylohyoid groove, mylohyoid muscle, mylohyoid branch and mylohyoid nerve (Federative International Programme for Anatomical Terminology-FIPAT, 2019).

The mylohyoid line is an oblique crest-shaped structure located on the inner face of the body of the mandible, which extends from the digastric fossa to the region of the lower third molar. Associated with this structure is the mylohyoid muscle, which extends from this line and inserts into the hyoid bone. The mylohyoid groove extends from the lingula of the mandible, to the submandibular fossa. Near to these structures, we find the mylohyoid neurovascular bundle.

The aim of this study was to investigate the etymology of the mylos root, for contributing to the understanding of $T A$ and discuss whether the use of this term in mylohyoid structures is appropriate.

\footnotetext{
${ }^{1}$ Doctorado en Ciencias Morfológicas, Universidad de La Frontera, Temuco, Chile.

${ }^{2}$ Centro de Excelencia en Estudios Morfológicos y Quirúrgicos, Universidad de La Frontera, Temuco, Chile.

${ }^{3}$ Núcleo de Idiomas, Facultad de Estudios Interdisciplinarios, Universidad Mayor, Temuco, Chile.
} 


\section{MATERIAL AND METHOD}

A search was performed for all the anatomical structures that contain the word mylohyoid using the edition of $T A$ published by IFAA in 2011, to identify the anatomical location and to observe if there is an agreement between the structure and the function described.

The second Edition of the TA (International Anatomical Terminology) is pending approval by the General Assembly at the next Congress of IFAA in London (2019).

Then, the medical-biological, historical and etymological dictionary of the Universidad de Salamanca was consulted for the etymology of mylohyoid, which states that the word is composed by the terms mylos and hyoid. In order to obtain the meaning of the mylos root, a search was initially carried out using the Greek-Spanish dictionary and then, the Latin-Spanish dictionary.

\section{RESULTS}

Two tables were made to summarize the information obtained. From the FIPAT of the IFAA (Table I) and from the Greek-Spanish and Latin-Spanish dictionaries (Table II).

From the dictionary of the Universidad de Salamanca, the following definition of mylohyoid muscles was obtained: "Muscle located in the mouth floor, that extends from the inner face of the mandible to the hyoid bone; it helps to the oral openning".

This term is composed by the greek

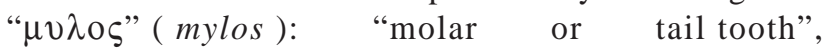

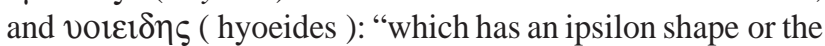
$\mathrm{Y}$ of the hyoid bone.

\section{DISCUSSION}

Considering the etymology of the mylohyoid word, is the mylos root the most appropriate term for naming the anatomical structures that coctain it. According to the Real Academia Española (RAE), the first definition for "mill" corresponds to "a stone disk that spins rapidly around an axis and over the hearth, to grind what is interposed between both stones." Therefore, it can be deduced that the term "molar" (relative to a mill) derives from this word by the similarity of its function with a mill. However, at present, the RAE also recognizes as a third meaning of molar "each of the teeth behind the canines that are used to grind or crush food."

When we observe the mylohyoid line we can see the first part extends to the level of the mental spines and digastric fossa, at the level of the lower incisors. And when we observe the mylohyoid groove we can see that it extends from an area further behind the third molar. Moreover, in the case of the mylohyoid line, groove and branch, they use the hyoid root in spite of the location of these bone structures is quite some distance from this bone.

There are other anatomical structures associated with the hyoid bone that present a similar case, for example the stylohyoid muscle, where "stylo" derives from the greek root stylos meaning "column or pillar" or in the case of the geniohyoid muscle where "geni" comes from the greek

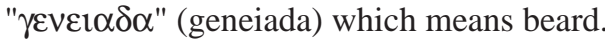

In these cases, the root was chosen because of its morphological similarity to the structures described, however, in the case of the geni root, we find a situation similar to the one with mylos, the meaning of which is far from the structure it want to describe. Thus, according to the RAE, the term beard is defined as "part of the face that is under the mouth" which determines a fairly wide anatomical area.

Table I. Terms with mylohyoid word in Terminologia Anatomica published by FIPAT (2011).

\begin{tabular}{llll}
\hline & Latin term & English term & Spanish term \\
\hline A02.1.15.012 & Linea mylohyoidea & Mylohyoid line & Línea milohioidea \\
A04.2.03.006 & M. mylohyoideus & M. mylohyoid & M. milohioideo \\
A14.2.01.090 & N. mylohyoideus & Nerve to mylohyoid & N. milohioideo \\
A02.1.15.031 & Sulcus mylohyoideus & Mylohyoid groove & Surco milohioideo \\
A12.2.05.060 & R. mylohyoideus & Mylohyoid branch & R. milohioidea \\
\hline
\end{tabular}

Table II. Search results in the Greek-Spanish dictionary and Latin-Spanish dictionary.

\begin{tabular}{|c|c|c|}
\hline Language & Root Mylos & Meaning \\
\hline Greek & 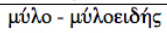 & Like a mill - resembling a molar tooth. \\
\hline Latin & Mola - $\propto f .:$ & $\begin{array}{l}\text { Mill grindstone // mill ( esp : in pl. Mol } \propto \text { - arum // mola or mola salsa, sacred } \\
\text { flour (from roasted wheat mixed with salt, which is spread over the victim's head) } \\
\text { // jaw. } \\
\text {-e: mill // - is : grinding wheel, huge stone }\end{array}$ \\
\hline
\end{tabular}


One of the proposal options would be to rename the mylohyoid structures based on a more precise location, which would give more information. In this regard, the mylohyoid line and groove could be referred to as the corpomandibular line and groove, referring to their location on the mandible's body.

In the same way the mylohyoid muscle could be called the corpohyoid muscle, just like the hyoglossus muscle, which extends from the hyoid bone and inserts into the tongue.

\section{CONCLUSION}

When proposing a change in Terminologia Anatomica, we must ensure that the new term accurately corresponds to the structure's description, either by shape or function, giving more precise information, that is, to submit an accurate and necessary change in $T A$.

WEN, S.; DEL SOL, M. \& NICHOLSON, C. Raíz mylos en Terminologia Anatomica. Int. J. Morphol., 38(1):126-128, 2020.

RESUMEN: La actual Terminologia Anatomica (TA), se encuentra redactada en latín y a partir de ella se realiza la traducción al idioma correspondiente. Existen en ella términos de origen griego que en ocasiones no describen a cabalidad la estructura anatómica. En este contexto la raíz mylos, presente en milohioideo(a), se define en griego "como de un molino" o "semejante a una muela", sin embargo, esta definición no precisa las estructuras milohioideas que se desean describir. Entonces surge la interrogante, ¿es la raíz mylos la más adecuada para denominar esas estructuras?

PALABRAS CLAVE: Terminologia Anatomica; Terminología Anatómica; Raíz mylos.

\section{REFERENCES}

Federative Committee on Anatomical Terminology (FCAT). Terminología Anatómica. Terminología Anatómica Internacional. Madrid, Panamericana, 2001.

Cortés, G. F. \& Bracero, J. Diccionario médico- biológico, histórico y etimológico. Ediciones Universidad de Salamanca, Salamanca, 2011. Disponible en: http://www.dicciomed.es

Dorland, W. Dorland's Illustrated Medical Dictionary. $31^{\text {st }}$ ed. Saunders, Philadelphia, 2007.

FIPAT. Terminologia Anatomica. Federative International Programme on Anatomical Terminologies, Stuttgart New York Thieme, New York, 2011.
FIPAT. Terminologia Anatomica. $2^{\mathrm{a}}$ ed. FIPAT.library.dal.ca. Federative International Programme for Anatomical Terminologies, 2019.

Fuentes, R. \& Ottone, N. Propuesta sobre la inclusión y eliminación de términos anatómicos en Terminología Anatómica correspondientes a la articulación témporomandibular. Int. J. Morphol., 35(1):12-5, 2017.

Moore, K. L. \& Agur, A. M. R. Fundamentos de Anatomía con Orientación Clínica. Wolters Kluwer/Lippincott Williams \& Wilkins, Barcelona, 2009.

Moya, M. P.; Contreras, M. \& del Sol, M. Lexema phy-sis en Terminologia Anatomica. Int. J. Morphol., 35(3): 919-24, 2017.

Pabón, J. M. Diccionario Manual Griego- Español. Vox, Madrid, 1967.

Real Academia Nacional de Medicina. Diccionario de Términos Médicos, Madrid, Medica Panamericana, 2011.

Smith, S. B.; Carmichael, S. W.; Pawlina, W.; Spinner, R. J. Latin and Greek in gross anatomy. Clin. Anat., 20(3):332-7, 2007.

Vásquez, B. \& del Sol, M. Terminologia Anatomica y Terminologia Histologica. Un lugar de encuentro entre los morfólogos. Int. J. Morphol., 33(4):1585-90, 2015.

Corresponding author:

Schilin Wen

Doctoral Program in Morphological Sciences

Universidad de La Frontera

Temuco

CHILE

Email: s.wen10@ufromail.cl

Received: 06-08-2019

Accepted: 21-09-2019 